\title{
Studi Kasus: Metode Pembelajaran Drill Berbantuan Open-Ended Problem untuk Mengembangkan Kemampuan Penalaran Matematis Siswa SMP
}

\author{
Arina Ulil Faroh ${ }^{1}$, Nuriana Rachmani Dewi ${ }^{2}$, Rochmad ${ }^{3}$ \\ ${ }^{1,2}$ Program Magister Pendidikan Matematika, Universitas Negeri Semarang, \\ Jl. Kelud Utara III Semarang 50237, Semarang, Jawa Tengah \\ Arinaauf17@students.unnes.ac.id
}

\begin{abstract}
The purpose that underlies the writing of this article is to determine students' mathematical reasoning abilities during the learning process using the drill method (practice) that utilizes open-ended problems on SPLDV material. The subjects of this study 20 students of class VIII SMP Dharma Lestari located in Pulutan Village. The type of research used is descriptive qualitative with a case study design. The data collection techniques used were observation, interviews, and open-ended problems description tests with four questions. The data analysis technique is scoring, students who have met the indicators will be given a score of 1 , and students who have not had the indicators are given a score of 0 . The results showed that some students did not have several indicators of mathematical reasoning ability. This can be seen in the scoring instrument table. This is due to students being less careful and not understanding the SPLDV material explained by the teacher at the previous meeting.
\end{abstract}

Keywords: Open-Ended Problem, Reasoning Mathematic

\begin{abstract}
Abstrak
Tujuan yang mendasari penulisan artikel ini untuk mengetahui kemampuan penalaran matematis siswa selama proses pembelajaran dengan metode drill (latihan) yang memanfaatkan soal open-ended problems pada materi SPLDV. Subjek penelitian ini adalah 20 siswa kelas VIII SMP Dharma Lestari di Desa Pulutan. Jenis penelitian yang digunakan adalah kualitatif deskriptif dengan desain studi kasus. Teknik pengumpulan data yang digunakan adalah observasi, wawancara, dan tes uraian open-ended problems sebanyak empat soal. Teknik analisis data yang adalah penskoran, siswa yang telah memenuhi indikator akan diberikan skor 1 dan siswa yang belum memenuhi indikator diberikan skor 0. Hasil penelitian menunjukkan bahwa beberapa siswa yang belum memiliki beberapa indikator kemampuan penalaran matematis. Hal ini dapat dilihat pada tabel instrumen penskoran. Hal tersebut diakibatkan siswa kurang teliti dan kurang memahami materi SPLDV yang dijelaskan guru pada pertemuan sebelumnya.
\end{abstract}

Kata kunci: Open-ended Problem, c

Copyright (c) 2022 Arina Ulil Faroh, Nuriana Rachmani Dewi, Rochmad

$\triangle$ Corresponding author: Arina Ulil Faroh

Email Address: Arinaauf17@students.unnes.ac.id (Jl. Kelud Utara III Semarang 50237, Semarang)

Received 12 December 2021, Accepted 29 January 2022, Published 14 February 2022

\section{PENDAHULUAN}

Mengingat pentingnya pendidikan, setiap negara mengatur proses pendidikan mereka. Saat ini pemerintah Indonesia mengatur pendidikan yang ada di Indonesia pada Kurikulum 2013. Terdapat beberapa cakupan materi matematika yang diatur pada Kurikulum. Setiap materi matematika pasti akan menyajikan masalah atau soal. Sehingga setiap siswa dituntut untuk memiliki beberapa kemampuan guna menyelesaikan permasalahan yang disajikan. National Council of Teacher of Mathematics (NCTM), menyebutkan "kemampuan matematika yang harus dimiliki siswa antara lain, pemecahan masalah, penalaran, komunikasi, koneksi, dan representasi" (Gita \& Marlina, 2019; Perwitasari \& Surya, 2017). Kemampuan matematika yang ada di NCTM sesuai dengan tujuan pembelajaran matematika yaitu agar siswa memiliki kemampuan penalaran pola dan sifat, melakukan manipulasi matematika, menciptakan generalisai, menyusun bukti dan memberikan pernyataan 
matematika (Wahyuni et al., 2019).

Penalaran merupakan kemampuan membangun skema permasalahan dan mengkomunikasikan pengetahuan yang telah dimiliki (Purwaningtyas, 2019). Penalaran dapat pula diartikan sebagai proses dalam memperoleh kesimpulan yang logis berdasarkan fakta-fakta yang telah dibuktikan (Firdausy et al., 2021; Gita \& Marlina, 2019; Hasanah et al., 2019; Mumu \& Tanujaya, 2019; Saleh et al., 2018). Penalaran dapat dikategorikan menjadi dua, yaitu penalaran induktif dan penalaran deduktif (Tao \& Cheng, 2021). Penalaran deduktif adalah proses pernyataan atau kesimpulan yang diperoleh dari kebenaran logis sebelumnya (Mandasari, 2021). Sedangkan penalaran induktif adalah penarikan kesimpulan setelah melihat kasus-kasus yang khusus (Fadillah, 2019; Yayuk, 2019). Matematika memiliki istilah penalaran matematis untuk menggambarkan beberapa penalaran atau indikator kemampuan yang harus dimiliki seorang siswa dalam menyelesaikan masalah. Kemampuan bernalar penting dimiliki siswa untuk dapat memahami matematika dan menyelesaikan masalah matematika (Mumu \& Tanujaya, 2019; Selvia et al., 2019). Seseorang dengan kemampuan penalaran yang tinggi akan mampu menyelesaikan soal dalam berbagai bentuk.

Penalaran matematis adalah kebiasaan otak yang apabila dikembangkan secara baik dan konsisten akan mudah mengkomunikasikan matematis lisan atau tertulis (Muslimin \& Sunardi, 2019). Penalaran matematika dapat memberikan anggapan yang kemudian menyusun pembuktian, serta memeriksa kebenaran suatu argumen dan menarik kesimpulan (Rizqi \& Surya, 2017). Kemampuan penalaran matematis penting dalam pemahaman matematis, mengembangkan ide, memperkirakan solusi, dan menerapkan ekspresi matematis (Santoso, 2013). Tabel 1 menunjukkan indikator kemampuan penalaran matematis menurut Peraturan Direktur Jenderal Pendidikan dan Kebudayaan No. 506/C/PP/2004 (Melani \& Sutirna, 2019; Muhammad, 2017; Ratnasari \& Abadi, 2018; Tambunan, 2018).

Tabel 1. Indikator Kemampuan Penalaran Matematis

\begin{tabular}{|c|l|}
\hline NO & \multicolumn{1}{|c|}{ Indikator Penalaran Matematis } \\
\hline 1 & Menyajikan pernyataan matematika secara lisan, tertulis, gambar, dan diagram. \\
\hline 2 & Mengajukan dugaan. \\
\hline 3 & Melakukan manipulasi matematis. \\
\hline 4 & $\begin{array}{l}\text { Menarik kesimpulan, menyusun bukti, memberikan alasan, atau bukti terhadap beberapa } \\
\text { solusi. }\end{array}$ \\
\hline 5 & Menarik kesimpulan dari pernyataan. \\
\hline 6. & Memeriksa kesahihan suatu argumen. \\
\hline 7. & Menemukan pola atau sifat dari gejala matematis untuk membuat generalisasi. \\
\hline
\end{tabular}

Kemampuan siswa tidak seketika muncul dimiliki siswa, akan tetapi dibutuhkan pembelajaran yang dilakukan guru dan siswa. Saat ini telah banyak berkembang metode pembelajaran yang dapat digunakan oleh guru. Penggunaan metode pembelajaran yang bervariasi dengan harapan siswa tidak akan bosan selama proses pembelajaran. Salah satu metode pembelajaran yang dapat digunakan oleh guru adalah metode pembelajaran drill. Metode pembelajaran drill merupakan salah satu strategi 
pembelajaran dengan memberikan latihan pada materi yang telah diajarkan (Hadi, 2019; Purnamasari et al., 2017; Sutarsih, 2020). Metode pembelajaran drill dapat diartikan sebagai metode pembelajaran dengan latihan (Kusumawati \& Irwanto, 2016). Latihan akan membiasakan siswa menghadapi berbagai macam soal yang disajikan (Hadi, 2019). Serta dengan latihan soal dapat meningkatkan kemampuan matematis siswa (Fransiska et al., 2019). Langkah-langkah metode pembelajaran drill diantaranya: (1) Memberikan penjelasan manfaat dan tujuan kepada siswa, (2) Dilaksanakan secara bertahap, (3) Memperhatikan kesulitan yang dihadapi siswa, (4) Mengutamakan ketelitian, (5) Memperhatikan waktu latihan agar siswa tidak bosan, (6) Memperhatikan perbedaan kemampuan individu (Rusyani et al., 2022). Melalui metode pembelajaran drill siswa diharapkan tidak hanya menghafal, akan tetapi fasih dalam menyelesaikan permasalahan atau operasi matematika (Hamidah et al., 2021). Selama proses pembelajaran guru dapat menggunakan berbagai macam soal, salah satu bentuk soal yang digunakan pada Kurikulum 2013 adalah soal open-ended problems. Open-ended problems merupakan soal terbuka yang memiliki jawaban dengan tidak hanya satu cara penyelesaian atau tidak hanya satu jawaban benar (Suyitno et al., 2017). Pada penelitian ini akan menggunakan open-ended problems dengan banyak cara penyelesaian. Sehingga dengan siswa dapat mengembangkan cara mereka sendiri tanpa ada batasan cara penyelesaian.

Kemampuan penalaran matematis menjadi salah satu kemampuan yang harus dikuasai siswa, namun siswa Indonesia masih tergolong rendah (Novianda et al., 2021). Hal tersebut dapat dilihat dari hasil TIMSS dan PISA. Rendahnya kemampuan penalaran siswa dapat ditemui pada materi Sistem Persamaan Linier Dua Variabel (SPLDV). SPLDV adalah materi aljabar yang menggabungkan pemodelan matematika dari soal cerita (Aulia et al., 2021; Meidiana et al., 2021; Yusuf \& Fitriani, 2020). Selain kesulitan dalam menyelesaikan soal cerita siswa masih terbiasa menghafal sehingga siswa kurang melibatkan penalaran (Pratiwi et al., 2021). Kurangnya teliti siswa selama mengerjakan soal dan siswa yang kurang menguasai materi pendukung sebelumnya (Maryani \& Setiawan, 2021).

Berdasarkan temuan peneliti pendahulu, masih ditemukan beberapa permasalah siswa yang tidak melibatkan kemampuan penalaran matematis sehingga siswa mengalami kesulitan dalam menyelesaikan masalah. Penelitian yang mendasari artikel ini berfokus padas kemampuan penalaran matematis siswa selama proses pembelajaran dengan metode drill menggunakan soal open-ended problems. Tujuan penelitian yang mendasari penulisan artikel ini untuk mengetahui kemampuan penalaran matematis siswa selama proses pembelajaran dengan model drill menggunakan soal openended problems.

\section{METODE}

Metode penelitian yang digunakan adalah kualitatif deskriptif dengan pendekatan studi kasus. Studi kasus merupakan penelitian yang lebih mendalami program, kejadian, dan proses (Creswell, 2021). Penelitian dilaksanakan di salah satu SMP yang terletak di Desa Pulutan pada tanggal 6 November hingga 6 Desember 2021. Subjek penelitian adalah siswa kelas VIII sejumlah 20 siswa. 
Teknik pengumpulan data yang digunakan pada penelitian adalah observasi, hasil tes, dan wawancara. Sedangkan teknik analisis data yang digunakan adalah penskoran, dimana siswa yang telah memenuhi indikator kemampuan penalaran akan mendapat point "1" sedangkan siswa yang belum memenuhi indikator kemampuan penalaran akan mendapat point " 0 ."

Indikator yang digunakan pada penelitian ini adalah (1) Menyajikan pernyataan matematika secara lisan dan tertulis, (2) Mengajukan dugaan, (3) Melakukan manipulasi matematika, (4) Menarik kesimpulan dan memberikan alasan, (5) Menarik kesimpulan dari pernyataan, (6) Memeriksa kesahihan suatu argumen, (7) Menemukan pola atau sifat dari gejala matematis untuk membuat generalisasi.

Penelitian diawali dengan kegiatan observasi, dimana peneliti mengamati siswa secara langsung selama proses pembelajaran bersama guru serta mengamati kemampuan matematis yang harus ditekankan pada siswa selama proses pembelajaran SPLDV. Setelah kegiatan observasi, peneliti melaksanakan pembelajaran dengan metode drill. Pelaksanaan pembelajaran dilaksanakan dengan memberikan soal sejumlah 4 soal berbentuk open-ended problems secara bertahap selama 2 jam pelajaran sebagai latihan. Setiap siswa yang telah selesai dengan satu soal maka peneliti melakukan pengkoreksian dan mengamati kemampuan penalaran matematis siswa berdasarkan lembar jawaban siswa. Kemudian peneliti memperkuat penelitian menggunakan wawancara dengan siswa yang dipilih secara acak (siswa DCL).

\section{HASIL DAN DISKUSI}

Penelitian diawali dengan observasi, yaitu melakukan pengamatan langsung pada siswa. Kegiaatan observasi bertujuan untuk mengetahui kemampuan matematis yang kurang dikuasai siswa. Setelah pelaksanaan observasi peneliti menyimpulkan bahwa siswa masih rendah dalam kemampuan penalaran matematis selama proses pembelajaran SPLDV. Sehingga peneliti memilih metode pembelajaran drill dengan soal open-ended problems untuk melihat lebih jauh kemampuan penalaran siswa. Soal diberikan satu persatu, siswa yang telah menyelesaikan satu soal hasil jawabannya diserahkan pada peneliti untuk dilakukan penilaian dan analisis.

Berdasarkan lembar jawab siswa terhadap empat soal, peneliti mampu mengamati dan menganalisis bahwa terdapat beberapa siswa belum memenuhi indikator kemampuan penalaran matematis. Hasil pengamatan dan analisis yang dilakukan pada siswa SMP kelas VIII materi SPLDV terhadap indikator kemampuan penalaran matematis siswa dapat dilihat pada Gambar 1. Berdasarkan Gambar 1, dapat dilihat bahwa siswa yang semula tidak menunjukkan indikator kemampuan penalaran, diakhir pemberian soal siswa telah mampu menunjukkan kemampuan pada beberapa indikator lainnya. Hal tersebut dapat diartikan bahwa metode pembelajaran drill dapat meningkatkan kemampuan penalaran matematis siswa (Hadi, 2019). Pemberian soal open-ended problems selama proses pembelajaran juga mampu mengembangkan kemampuan penalaran matematis, dimana siswa tidak hanya terpaku pada satu cara penyelesaian sehingga kemampuan penalaran siswa akan 
berkembang (Santoso, 2013). Berdasarkan observasi peneliti terdapat beberapa alasan siswa tidak memenuhi indikator kemampuan penalaran, diantaranya siswa kurang memahami akan materi sebelumnya (Maryani \& Setiawan, 2021). Siswa yang memiliki pemahaman akan materi sebelumnya (sistem persamaan linear satu variabel) maka akan mudah melakukan teknik eliminasi dan subsitusi. Selain itu siswa tidak teliti salama mengerjakan soal (Putri \& Isnaningrum, 2021).

\begin{tabular}{|c|c|c|c|c|c|c|c|c|c|c|c|c|c|c|c|c|c|c|c|c|c|c|c|c|c|c|c|c|}
\hline \multirow{2}{*}{ Siswa } & \multicolumn{7}{|c|}{ Soal 1} & \multicolumn{7}{|c|}{ Soal 2} & \multicolumn{7}{|c|}{ Soal 3} & \multicolumn{7}{|c|}{ Soal 4} \\
\hline & 1 & 2 & 3 & 4 & 5 & 6 & 7 & 1 & 2 & 3 & 4 & 5 & 6 & 7 & 1 & 2 & 3 & 4 & 5 & 6 & 7 & 1 & 2 & 3 & 4 & & 6 & 7 \\
\hline AA & 1 & 1 & 1 & 1 & 1 & 0 & 0 & 1 & 1 & 1 & 1 & 1 & 0 & 0 & 1 & 1 & 1 & 1 & 1 & 0 & 0 & 1 & 1 & 1 & 1 & 1 & 1 & 1 \\
\hline AFM & 1 & 1 & 1 & 1 & 1 & 0 & 0 & 1 & 1 & 1 & 1 & 1 & 0 & 0 & 1 & 1 & 1 & 1 & 1 & 0 & 0 & 1 & 1 & 1 & 1 & 1 & 1 & 1 \\
\hline AG & 1 & 1 & 1 & 0 & 1 & 0 & 0 & 1 & 1 & 1 & 1 & 1 & 1 & 0 & 1 & 1 & 1 & 1 & 1 & 1 & 1 & 1 & 1 & 1 & 1 & 1 & 1 & 1 \\
\hline AJ & 1 & 1 & 1 & 0 & 0 & 0 & 0 & 1 & 1 & 1 & 0 & 1 & 0 & 0 & 1 & 1 & 1 & 1 & 1 & 1 & 0 & 1 & 1 & 1 & 1 & 1 & 0 & 0 \\
\hline ASH & 1 & 1 & 1 & 0 & 0 & 0 & 0 & 1 & 1 & 1 & 0 & 1 & 0 & 0 & 1 & 1 & 1 & 1 & 1 & 1 & 1 & 1 & 1 & 1 & 1 & 1 & 1 & 1 \\
\hline $\mathrm{D}$ & 1 & 1 & 1 & 0 & 0 & 0 & 0 & 1 & 1 & 1 & 0 & 1 & 0 & 0 & 1 & 1 & 1 & 1 & 1 & 0 & 0 & 1 & 1 & 1 & 1 & 1 & 1 & 1 \\
\hline $\mathrm{DA}$ & 1 & 1 & 1 & 1 & 1 & 0 & 0 & 1 & 1 & 1 & 0 & 1 & 0 & 0 & 1 & 1 & 1 & 1 & 1 & 0 & 0 & 1 & 1 & 1 & 1 & 1 & 1 & 1 \\
\hline DCL & 1 & 1 & 1 & 0 & 0 & 0 & 0 & 1 & 1 & 1 & 0 & 1 & 0 & 0 & 1 & 1 & 1 & 1 & 1 & 0 & 1 & 1 & 1 & 1 & 1 & 1 & 1 & 1 \\
\hline LA & 1 & 1 & 1 & 0 & 0 & 0 & 0 & 1 & 1 & 1 & 1 & 1 & 0 & 0 & 1 & 1 & 1 & 1 & 1 & 0 & 0 & 1 & 1 & 1 & 1 & 1 & 1 & 1 \\
\hline MAI & 1 & 0 & 1 & 0 & 0 & 0 & 0 & 1 & 1 & 1 & 0 & 0 & 0 & 0 & 1 & 1 & 1 & 0 & 1 & 0 & 0 & 1 & 1 & 1 & 1 & 1 & 1 & 1 \\
\hline MHP & 1 & 1 & 1 & 0 & 1 & 0 & 0 & 1 & 1 & 1 & 1 & 1 & 0 & 0 & 1 & 1 & 1 & 1 & 1 & 0 & 0 & 1 & 1 & 1 & 1 & 1 & 1 & 1 \\
\hline $\mathrm{N}$ & 1 & 1 & 1 & 1 & 1 & 0 & 0 & 1 & 1 & 1 & 1 & 1 & 0 & 0 & 1 & 1 & 1 & 1 & 1 & 0 & 0 & 1 & 1 & 1 & 1 & 1 & 1 & 1 \\
\hline NK & 1 & 1 & 1 & 0 & 1 & 0 & 0 & 1 & 1 & 1 & 1 & 1 & 0 & 0 & 1 & 1 & 1 & 0 & 0 & 0 & 0 & 1 & 1 & 1 & 0 & 1 & 0 & 0 \\
\hline NTM & 1 & 1 & 1 & 0 & 1 & 0 & 0 & 1 & 1 & 1 & 1 & 1 & 1 & 1 & 1 & 1 & 1 & 1 & 1 & 1 & 1 & 1 & 1 & 1 & 1 & 1 & 1 & 1 \\
\hline $\mathrm{RP}$ & 1 & 0 & 1 & 0 & 0 & 0 & 0 & 1 & 1 & 1 & 0 & 0 & 0 & 0 & 1 & 1 & 1 & 0 & 0 & 0 & 0 & 1 & 1 & 1 & 0 & 1 & 0 & 0 \\
\hline $\mathrm{RR}$ & 1 & 0 & 0 & 0 & 0 & 0 & 0 & 1 & 1 & 1 & 0 & 0 & 0 & 0 & 1 & 1 & 1 & 0 & 0 & 0 & 0 & 1 & 1 & 1 & 0 & 1 & 0 & 0 \\
\hline SZS & 1 & 0 & 1 & 0 & 0 & 0 & 0 & 1 & 1 & 1 & 0 & 0 & 0 & 0 & 1 & 1 & 1 & 0 & 0 & 0 & 0 & 1 & 1 & 1 & 0 & 1 & 0 & 0 \\
\hline $\mathrm{TA}$ & 1 & 0 & 0 & 0 & 0 & 0 & 0 & 1 & 1 & 1 & 0 & 1 & 0 & 0 & 1 & 1 & 1 & 1 & 1 & 1 & 1 & 1 & 1 & 1 & 1 & 1 & 1 & 1 \\
\hline $\mathrm{TR}$ & 1 & 1 & 1 & 1 & 1 & 0 & 0 & 1 & 1 & 1 & 1 & 1 & 1 & 1 & 1 & 1 & 1 & 1 & 1 & 1 & 1 & 1 & 1 & 1 & 1 & 1 & 1 & 1 \\
\hline $\mathrm{ZR}$ & 1 & 1 & 1 & 0 & 1 & 0 & 0 & 1 & 1 & 1 & 1 & 1 & 0 & 0 & 1 & 1 & 1 & 1 & 1 & 0 & 1 & 1 & 1 & & 1 & 1 & 1 & 1 \\
\hline
\end{tabular}

Gambar 1. Kemampuan Penalaran Matematis Siswa Kelas VIII Berdasarkan Indikator

\section{Pembahasan Penalaran Matematis Tes 1 (Siswa DCL)}

Berdasarkan Gambar 2 terkait hasil penyelesaian soal 1 oleh siswa DCL menunjukkan bahwa siswa tidak mampu menyelesaikan masalah dengan benar. Dan siswa tidak mampu merespon 4 indikator terakhir dari 7 indikator kemampuan penalaran matematis. Sedangkan indikator 3 indikator pertama dari 7 indikator kemampuan penalaran matematis telah mampu dikuasai siswa. Hal tersebut diperkuat dengan hasil wawancara siswa dan peneliti. 


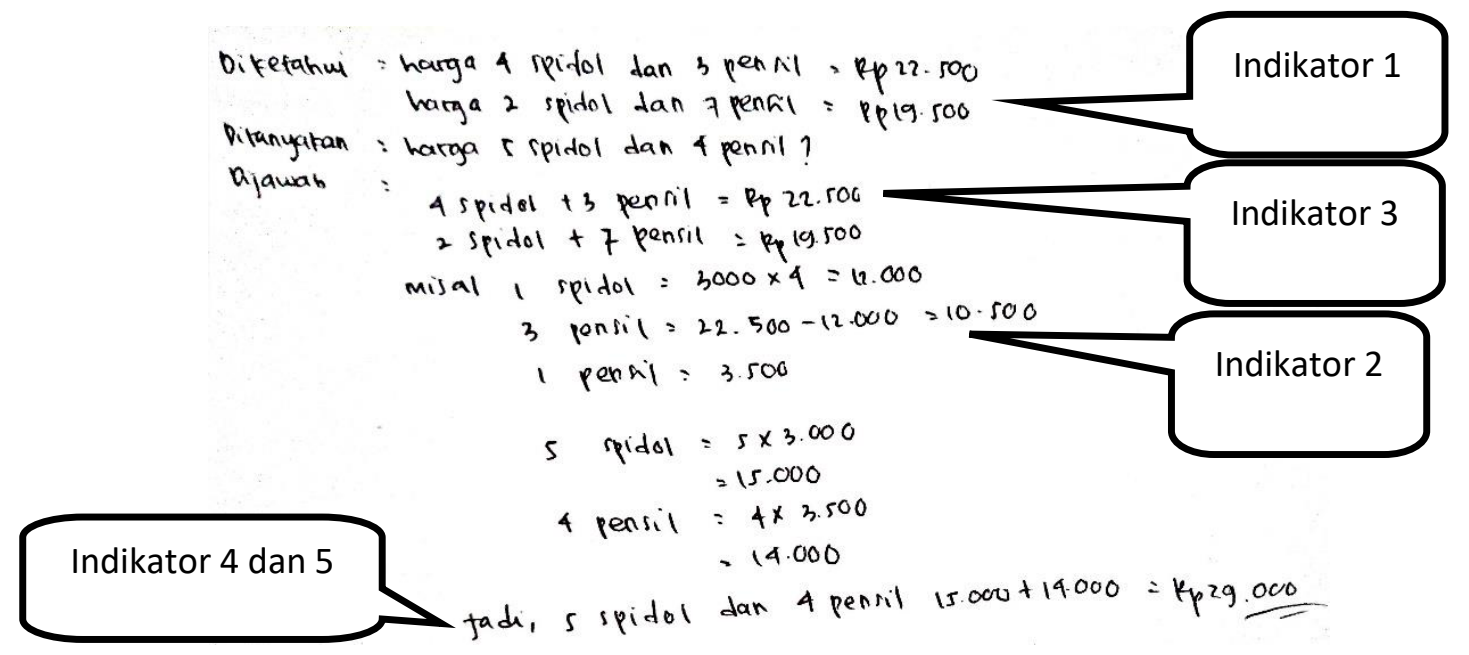

Gambar 2. Hasil Penyelesaian Soal 1 Siswa DCL

Berikut ini adalah penjelasan tentang kemampuan penalaran siswa pada tes 1.

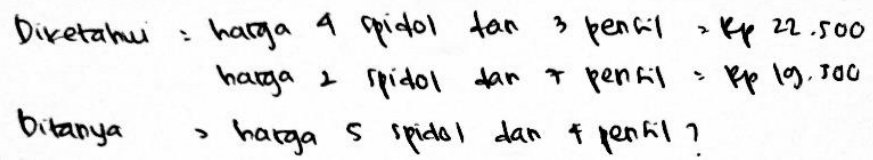

Gambar 3. Hasil Penyelesaian Soal 1 Siswa DCL (Indikator 1)

Berdasarkan Gambar 3, menunjukkan bahwa siswa telah mampu menyajikan pernyataan matematika secara tertulis. Ditunjukkan dengan siswa dapat menuliskan apa yang diketahui dan ditanyakan pada soal. Sedangkan mampu menyajikan pernyataan matematika secara lisan diperoleh dari wawancara, berikut hasil wawancara dengan siswa.

Peneliti : "Apa saja yang diketahui pada soal?"

DCL : : "Yang diketahui harga 4 spidol sama 3 pensil itu Rp 22.500, 2 spidol dengan 7 pensil Rp 19.500.”

Peneliti : "Apa yang ditanyakan pada soal tersebut?"

DCL : "Harga 5 spidol dan 4 pensil."

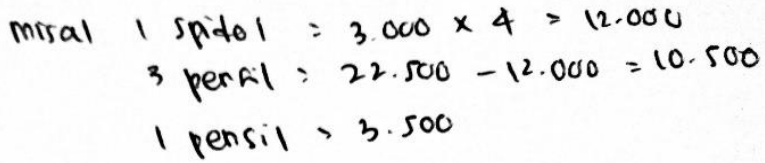

Gambar 4. Hasil Penyelesaian Soal 1 Siswa DCL (Indikator 2)

Berdasarkan Gambar 4, menunjukkan bahwa siswa mampu untuk menduga suatu penyelesaian dari soal yang disajikan, dengan melakukan pemisalan dan memanfaatkan apa yang diketahui pada soal. Walaupun dalam kasus siswa DCL ditemui kesalahan pada proses menduga harga 1 spidol, siswa hanya mengamati harga dari 1 pernyataan yang ada pada soal tanpa memperhatikan yang lain. Kesalahan dalam proses menduga dikarena siswa kurang memahami materi SPLDV yang sebelumnya 
telah diberikan oleh guru (Saputri et al., 2017).

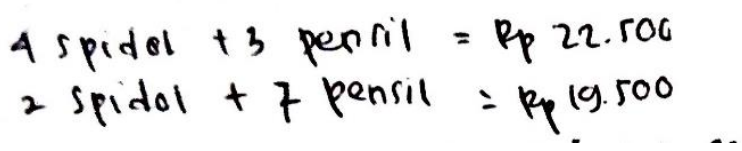

Gambar 5. Hasil Penyelesaian Soal 1 Siswa DCL (Indikator 3)

Berdasarkan Gambar 5, menunjukkan indikator 3 kemampuan penalaran matematis yaitu melakukan manipulasi matematika dari soal cerita yang diubah menjadi operasi matematika. Ditunjukkan dengan siswa mampu mengubah kata "dan" menjadi “+”. Berdasarkan hasil wawancara siswa dapat menjelaskan proses manipulasi matematika yang dilakukannya, berikut hasil wawancara dengan siswa:

Peneliti : "Apa yang kamu lakukan untuk mengubah soal cerita menjadi operasi matematika?" DCL : "Mengganti kata dan jadi +."

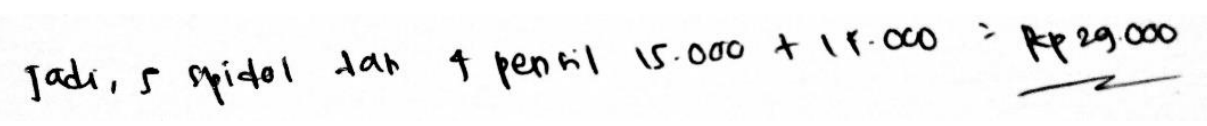

Gambar 6. Hasil Penyelesaian Soal 1 Siswa DCL (Indikator 4 dan 5)

Berdasarkan Gambar 6, dapat disimpulkan bahwa siswa telah mampu membuat kesimpulan, akan tetapi siswa tidak dapat menunjukkan bukti, membuat alasan atau bukti terhadap solusi yang disajikan pada soal tersebut, serta kesimpulan siswa tidak sesuai pertanyaan yang ada di soal. Selain itu siswa juga tidak menunjukkan indikator 5, dimana siswa DCL tidak tepat dapat memberikan kesimpulan menjadi sebuah pernyataan, kesimpulan yang diberikan masih dalam berbentuk matematis. Akan lebih tepat bila siswa memberikan kesimpulan "Jadi, harga 5 spidol dan 4 pensil adalah Rp 29.000." Serta kesimpulan yang diberikan siswa tidak benar. Hal tersebut dikuatkan dengan hasil wawancara dengan siswa dimana siswa tidak mampu untuk menunjukkan indikator 4 dan 5 . Siswa selama proses wawancara hanya dapat memberikan jawaban "belum", "tidak tau" dan hanya merespon diam saat ditanyakan bukti jawabannya benar atau salah. Siswa lebih sering hanya mampu untuk mengerjakan soal berdasarkan materi yang telah dipelajari tanpa mampu membuktikan kebenaran dari jawabannya (Putri \& Isnaningrum, 2021).

Indikator 6 belum ditunjukkan siswa DCL selama proses wawancara dan lembar jawab soal. Memeriksa kesahihan suatu argemen, siswa tidak melakukan pemeriksaan ulang terhadap jawabannya dan selama wawancara siswa hanya terdiam. Indikator 7 juga belum ditunjukkan siswa DCL dalam lembar jawab soal dan hasil wawancara. Menemukan pola atau sifat dari gejala matematis untuk membuat generalisasi. Indikator 4 hingga 7 menjadi kemampuan yang sulit dipahami oleh siswa, hal tersebut diakibatkan oleh kurang telitinya siswa selama mengerjakan soal dan siswa kurang memahami materi (Saputri et al., 2017). 
Pembahasan Penalaran Matematis Tes 2 (Siswa DCL)

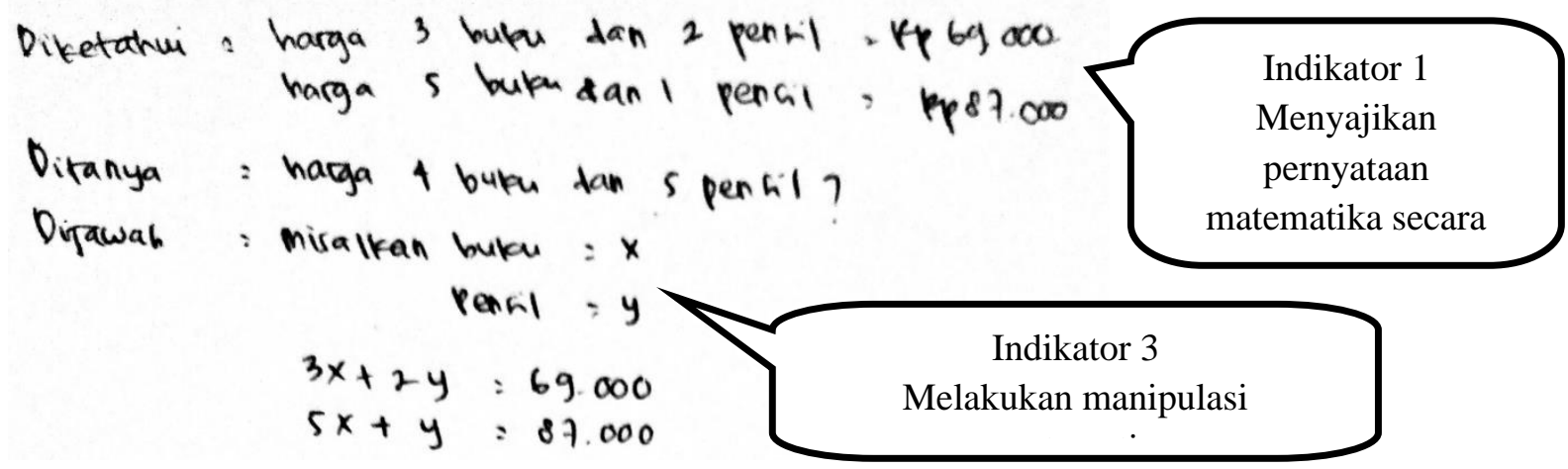

Gambar 7. Hasil Penyelesaian Soal 4 Siswa DCL (Indikator 1 dan 3)

Berdasarkan Gambar 7, dilihat bahwa siswa telah mampu untuk menuliskan apa yang diketahui "harga 3 buku dan 2 pensil = Rp 69.000 dan harga 5 buku dan 1 pensil Rp 87.000." serta siswa telah menuliskan apa yang ditanyakan "harga 4 buku dan 5 pensil." Selain itu Gambar 6 menunjukkan bahwa siswa memenuhi indikator 3 yaitu melakukan manipulasi matematika dengan siswa mengubah "buku" dan "pensil" menggunakan pemisalan "buku dengan $x$ " serta "pensil dengan $y$ ", kata "dan" yang ada pada soal dirubah menjadi simbol matematika "+". Hasil analisis peneliti diperkuat dengan hasil wawancara siswa "Memisalkan $x$ itu buku dan $y$ itu pensil, biar lebih mudah waktu eliminasi dan subsitusi."

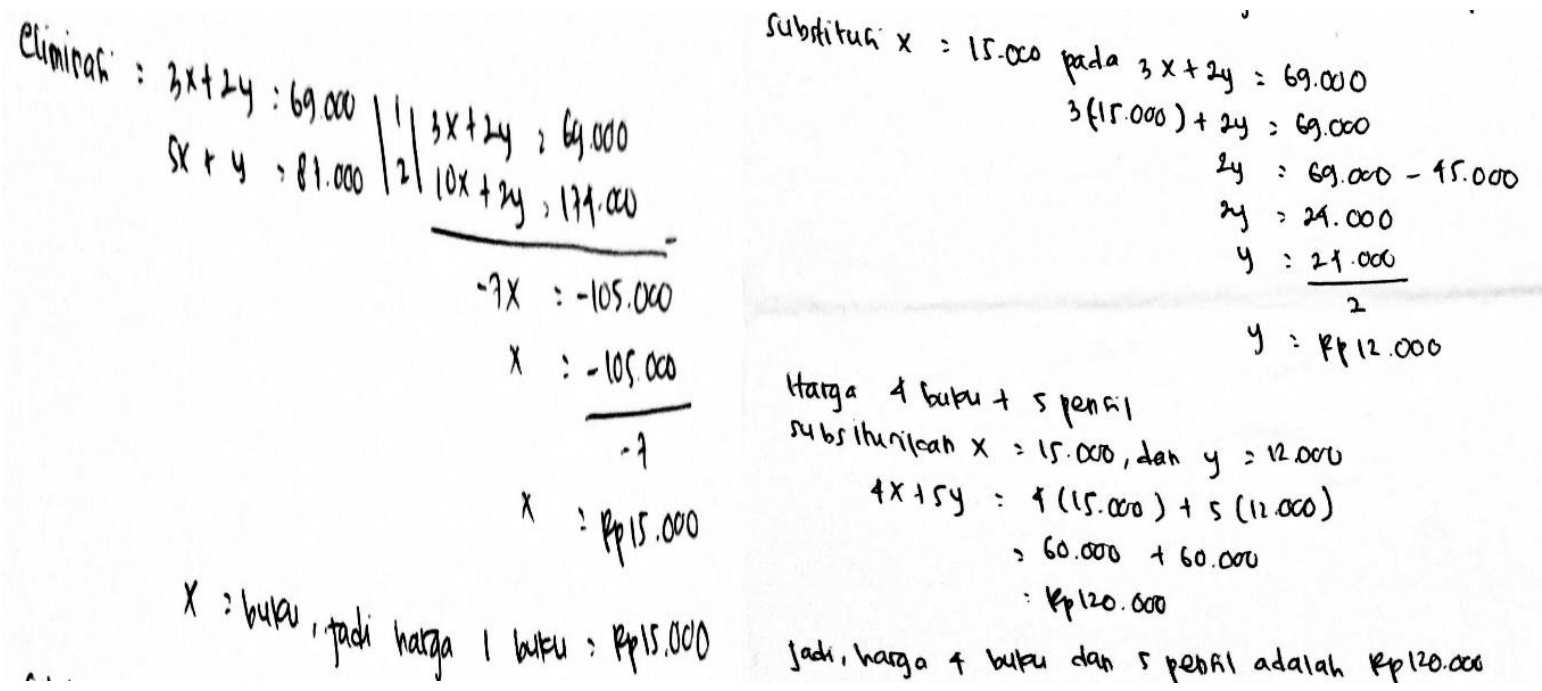

Gambar 8. Hasil Penyelesaian Soal 4 Siswa DCL (Indikator 2, 4 hingga 7)

Berdasarkan Gambar 8, siswa telah menunjukkan kemampuan penalaran indikator 2 hingga 7. Indikator 2 yaitu mengajukan dugaan, dimana siswa memberikan jawaban "Soal kayak gini bisa pakai eliminasi dan subsitusi." Indikator 4 yaitu menarik kesimpulan dan memberikan alasan, kesimpulan yang diberikan siswa benar. Siswa teliti selama mengerjakan soal dan dapat membuktikan jawaban selama proses wawancara, dengan memberikan jawaban "Bisa, kalau harga 1 buku itu 15.000 dikali 4 berarti 60.000, terus harga 1 pensil kan 12.000 dikali 5 itu 60.000, terus dijumlah hasilnya 120.000 , 
kalau harga 1 buku dikali 3 kan 45.000, terus harga 1 pensil dikali 2 kan 24.000 kalau dijumlah 69.000 sama kayak yang diketahui." Indikator 5 yaitu menarik kesimpulan dari pernyataan. "Jadi, harga 4 buku dan 5 pensil adalah Rp 120.000." Pernyataan tersebut menunjukkan bahwa siswa mengubah kembali jawabannya menjadi pernyataan yang diminta pada soal. Indikator 6 yaitu menarik kesahihan dari suatu argumen, siswa menjawab soal dengan benar dan selama wawancara siswa menyatakan telah melakukan pengkoreksian sebelum menuliskan kesimpulan. Indikator 7, yaitu menentukan pola pola atau sifat dari gejala matematis untuk membuat generalisasi. Berdasarkan 4 hasil pengerjaan soal yang dilakukan siswa sebelumnya tidak menerapkan eliminasi dan subsitusi, diakhir soal telah menggunakan cara eliminasi dan subsitusi.

\section{KESIMPULAN}

Kemampuan penalaran matematis menjadi salah satu yang ditetapkan oleh NCTM untuk dimiliki siswa. Matematika merupakan materi pelajaran yang akan selalu memberikan masalah, sehingga dibutuhkan kemampuan penalaran matematis untuk mampu menyelesaikan berbagai bentuk masalah. Sistem Persamaan Linier Dua Variabel (SPLDV) salah satu materi yang menyajikan masalah dalam bentuk soal cerita. Soal cerita menjadi salah satu materi yang sulit dipahami bila siswa tidak menguasai kemampuan penalaran. Tujuh indikator kemampuan penalaran yang ditetapkan oleh Peraturan Direktur Jenderal Pendidikan dan Kebudayaan No. 506/C/PP/2004. Selama proses pembelajaran dengan metode drill (latihan) diberikan soal open-ended problems dimana siswa akan lebih kreatif dan dapat mengembangkan kemampuan penalarannya. Dari hasil penelitian siswa mengalami perkembangan kemampuan penalaran dari yang belum memenuhi beberapa indikator diakhir pembelajaran hanya tinggal beberapa siswa yang belum memenuhi indikator. Siswa DCL yang menjadi sampel penelitian, diawal soal hanya mampu memenuhi 3 indikator, disetiap soal indikator yang dikuasai semakin bertambah. Siswa yang tidak memnuhi indikator kemampuan penalaran tersebut karena siswa kurang teliti dan kurang memahami materi yang diajarkan guru dipertemuan sebelumnya. Model pembelajaran drill menggunakan soal open-ended problems dapat menjadi salah satu solusi untuk mengembangkan kemampuan penalaran matematis.

\section{REFERENSI}

Aulia, D., Kusuma, C., Sujadi, I., \& Slamet, I. (2021). The Advantages of Pemalang Area-Based SPLDV Questions Development. 597, 82-89.

Creswell, J. W. (2021). Research Design Pendekatan Metode Kualitatif, Kuantitatif, dan Campuran. Pustaka Pelajar.

Fadillah, A. (2019). Analisis Kemampuan Penalaran Deduktif Matematis Siswa. JTAM | Jurnal Teori Dan Aplikasi Matematika, 3(1), 15. https://doi.org/10.31764/jtam.v3i1.752

Firdausy, A. R., Triyanto, \& Indriati, D. (2021). Creative Thinking Based on Mathematical Reasoning

Ability in Solving Geometry Problems in High School. Proceedings of the International 
Studi Kasus: Metode Pembelajaran Drill Berbantuan Open-Ended Problem untuk Mengembangkan Kemampuan

Conference of Mathematics and Mathematics Education, 597, 14-24.

Fransiska, C., Masykur, R., \& Putra, F. G. (2019). Analisis Kemampuan Pemecahan Masalah Matematis : Dampak Metode Drill ditinjau dari Gaya Belajar. Desimal: Jurnal Matematika, 2(2), 131-140. https://doi.org/10.24042/djm.v2i2.4147

Gita, T. I. P., \& Marlina, R. (2019). Kemampuan Penalaran Matematis Siswa Kelas IX Pada Materi Persamaan Linear Dua Variabel (SPLDV). Prosiding Seminar Nasional Matematika Dan Pendidikan Matematika Sesiomadika 2019, 1045-1051.

Hadi, A. (2019). Peningkatan Hasil Belajar Matematika melalui Strategi Interaktif dengan Menggunakan Metode Pembelajaran Drill pada Siswa Kelas XI MIPA 6 SMA Negeri 16 Makassar. EQUALS Jurnal Ilmiah Pendidikan Matematika, 2(2), 53-61. http://ejournals.umma.ac.id/index.php/equals/article/view/375

Hamidah, Junaedi, I., Mulyono, \& Kusuma, J. W. (2021). Kurikulum dan Pembelajaran Matematika di Jepang dan di Indonesia. Jurnal Pendidikan Matematika, 7(2), 153-167.

Hasanah, S. I., Tafrilyanto, C. F., \& Aini, Y. (2019). Mathematical Reasoning: The characteristics of students 'mathematical abilities in problem solving Mathematical. IOP Conference. https://doi.org/10.1088/1742-6596/1188/1/012057

Kusumawati, E., \& Irwanto, R. A. (2016). Penerapan Metode Pembelajaran Drill untuk Meningkatkan Kemampuan Pemecahan Masalah Matematis Siswa Kelas VIII SMP. EDU-MAT, 4(April), 4957.

Mandasari, N. (2021). Problem-based learning model to improve mathematical reasoning ability. Journal of Physics: Conference Series, 1731(1). https://doi.org/10.1088/1742$6596 / 1731 / 1 / 012041$

Maryani, A., \& Setiawan, W. (2021). Analisis Kesulitan Peserta Didik Kelas VIII dalam Menyelesaikan Soal Sistem Persamaan Linear Dua Variabel (SPLDV) di MTs Atsauri Sindangkerta. Jurnal Cendekia: Jurnal Pendidikan Matematika, 5(3), 2619-2627. https://doi.org/10.31004/cendekia.v5i3.915

Meidiana, S., Nyimas, A., Indaryanti, \& Pratiwi, W. D. (2021). Investigating Student's Mathematical Reasoning Ability by Using PMRI Based on Emergent Modeling. Proceedings of the 1st International Conference on Mathematics and Mathematics Education (ICMMEd 2020), 550(Icmmed 2020), 339-344. https://doi.org/10.2991/assehr.k.210508.085

Melani, F., \& Sutirna. (2019). Analisis kemampuan penalaran matematis siswa smp kelas viii pada materi relasi dan fungsi. Prosiding Seminar Nasional Matematika Dan Pendidikan Matematika Sesiomadika, 188-193.

Muhammad, G. M. (2017). PADA MATA KULIAH STRUKTUR ALJABAR II. Jurnal PRISMA Universitas Suryakancana, VI(1), 66-78.

Mumu, J., \& Tanujaya, B. (2019). Measure reasoning skill of mathematics students. International Journal of Higher Education, 8(6), 85-91. https://doi.org/10.5430/ijhe.v8n6p85 
Muslimin, \& Sunardi. (2019). Analisis Kemampuan Penalaran Matematika Siswa SMA pada Materi Geometri Ruang. Kreano, 10(2), 171-178.

Novianda, D., Darhim, \& Prabawanto, S. (2021). Analysis of students' mathematical reasoning ability in geometry through distance learning. Journal of Physics: Conference Series, 1882(1). https://doi.org/10.1088/1742-6596/1882/1/012085

Perwitasari, D., \& Surya, E. (2017). The Development of Learning Material Using Problem Based Learning to Improve Mathematical Communication Ability of Secondary School Students. International Journal of Sciences: Basic and Applied Research (IJSBAR) International Journal of Sciences: Basic and Applied Research, 33(3), 200-207. http://gssrr.org/index.php?journal=JournalOfBasicAndApplied

Pratiwi, N., Aisyah, N., Susanti, E., \& Pratiwi, W. D. (2021). Analysis of Junior High School Student's Mathematical Reasoning Ability in Solving Non-routine Problems on Material of Two-variable Linear Equation Systems. Proceedings of the 1st International Conference on Mathematics and Mathematics Education (ICMMEd 2020), 550(Icmmed 2020), 318-326. https://doi.org/10.2991/assehr.k.210508.082

Purnamasari, M., Isman, J., Damayanti, A., \& Ismah. (2017). Upaya Meningkatkan Hasil Belajar Matematika Terhadap Konsep Bangun Ruang materi luas dan volume balok dan kubus menggunakan metode drill sekolah smp islam al-ghazali kelas viii. FIBONACI: Jurnal Pendidikan Matematika \& Matematika, 3(1), 45-52.

Purwaningtyas, K. (2019). PENALARAN SISWA SMP TERHADAP SOAL GEOMETRI TIPE. APOTEMA: Jurnal Program Studi Pendidikan Matematika, 5(2), 95-102.

Putri, A. A., \& Isnaningrum, I. (2021). Analisis Kemampuan Penalaran Matematis Pada Materi Sistem Persamaan Linear Dua Variabel. Diskusi Panel Nasional ..., 10, 201-210. http://www.proceeding.unindra.ac.id/index.php/DPNPMunindra/article/view/5523

Ratnasari, G. I., \& Abadi, A. M. (2018). Investigating mathematical literacy, mathematical reasoning skill, and self esteem of a public high school. Journal of Physics: Conference Series, 1097(1). https://doi.org/10.1088/1742-6596/1097/1/012096

Rizqi, N. R., \& Surya, E. (2017). AN ANALYSIS OF STUDENTS ' MATHEMATICAL REASONING ABILITY IN VIII GRADE OF SABILINA TEMBUNG JUNIOR. IJARIIE, 3(2), $3527-3533$.

Rusyani, E., Ratnengsih, E., Putra, A. S., Maryanti, R., Fitria, D., Husaeni, A., \& Ragadhita, R. (2022). Indonesian Journal of Community and The Drilling Method Application Using Abacus to Arithmetic Operations Skills in Student with Hearing Impairment at Special School. 2(1), 110.

Saleh, M., Charitas, R., Prahmana, I., \& Isa, M. (2018). Improving the Reasoning Ability of Elementary School Student Through the Indonesian Realistic. Journal on Mathematics Education, 9(1), 41-54. https://ejournal.unsri.ac.id/index.php/jme/article/view/5049 
Studi Kasus: Metode Pembelajaran Drill Berbantuan Open-Ended Problem untuk Mengembangkan Kemampuan

Santoso, A. S. (2013). Pengaruh Pemberian Soal Open-Ended Terhadap Kemampuan Penalaran Matematis Siswa. Kreano, Jurnal Matematika Kreatif-Inovatif, 4(2), 138-150. https://doi.org/10.15294/kreano.v4i2.3138

Saputri, I., Susanti, E., \& Aisyah, N. (2017). Kemampuan Penalaran Matematis Siswa Menggunakan Pendekatan Metaphorical Thinking pada Materi Perbandingan Kelas VIII di SMPN 1 Indralaya Utara. Jurnal Elemen, 3(1), 15. https://doi.org/10.29408/jel.v3i1.302

Selvia, S., Rochmatin, T., \& Zanthy, L. S. (2019). Analisis Kemampuan Pemecahan Masalah Dan Kemampuan Penalaran Matematik Siswa Smp Pada Materi Spldv. JPMI (Jurnal Pembelajaran Matematika Inovatif), 2(5), 261. https://doi.org/10.22460/jpmi.v2i5.p261-270

Sutarsih, N. W. (2020). Penerapan Model Pembelajaran Direct Instruction Dengan Metode Drill Guna Meningkatkan Prestasi Belajar Matematika Siswa Kelas IX E Semester I SMP Negeri 1 Tampaksiring Tahun Pelajaran 2018/2019. Widyadari, 27(27), 1-13.

Suyitno, A., Suyitno, H., Rochmad, \& Dwijanto. (2017). Use of open-ended problems as the basis for the mathematical creativity growth disclosure of student. International Conference on Mathematics, Science, and Education, 0-5. https://doi.org/10.1088/1742-6596/983/1/012110

Tambunan, H. (2018). Impact of Heuristic Strategy on Students' Mathematics Ability in High Order Thinking. International Electronic Journal of Mathematics Education, 13(3), 321-328. https://doi.org/10.12973/iejme/3928

Tao, L., \& Cheng, J. (2021). The application of discrete mathematics to microeconomics. Journal of Physics: Conference Series, 1955(1). https://doi.org/10.1088/1742-6596/1955/1/012046

Wahyuni, E. S., Hadi, A. F., Subekti, F. E., Simanjuntak, E., \& Hutabarat, H. D. M. (2019). Gender and mathematical reasoning ability. https://doi.org/10.1088/1742-6596/1157/4/042109

Yayuk, E. (2019). Pembelajaran Matematika SD. Universitas Muhammadiyah Malang.

Yusuf, A., \& Fitriani, N. (2020). Analisis kesalahan siswa smp dalam menyelesaikan soal persamaan linear dua variabel di SMPN 1 campaka mulya-cianjur. Jurnal Pembelajaran Matematika Inovatif, 3(1), 59-68. https://doi.org/10.22460/jpmi.v3i1.p59-68. 